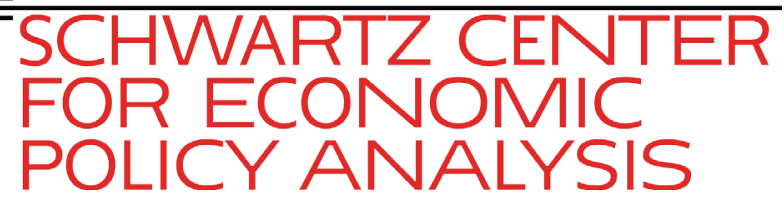

\title{
Retirement Plan Wealth Inequality: Measurement and Trends
}

\section{Teresa Ghilarducci, Siavash Radpour, and Anthony Webb}

\author{
Schwartz Center for Economic Policy Analysis (SCEPA) \\ Department of Economics \\ The New School for Social Research \\ 6 East 16th Street, New York, NY 10003 \\ economicpolicyresearch.org
}

Suggested Citation: Ghilarducci, T., Radpour, S. and Webb, A. (2019) "Retirement Plan Wealth Inequality: Measurement and Trends." Schwartz

Center for Economic Policy Analysis and

Department of Economics, The New School for

Social Research, Working Paper Series 2019-1. 


\section{Cover Page}

Retirement Plan Wealth Inequality: Measurement and Trends

\section{Teresa Ghilarducci}

Siavash Radpour

Anthony Webb

The New School for Social Research

\section{Abstract (100 words)}

Using Health and Retirement Study data linked to summary plan descriptions and W-2s, this study reports trends in retirement wealth inequality of older employees 1992-2010. The study identifies and corrects methodological flaws in past research. Retirement wealth is highly unequally distributed; the top lifetime earnings quintile holds half of all retirement wealth, the bottom quintile, only 1 percent. The top earnings quintile fared better in 2010 than in 1992, whereas bottom-quintile earners fared worse. But retirement wealth inequality mainly reflects inequality within earnings quintiles, resulting from inadequate savings, not outsize accumulations. Systemic flaws reduce median retirement wealth by 84 percent.

Keywords: Retirement, wealth, inequality.

Corresponding author: Anthony Webb webbt@newschool.edu

We thank Gary Engelhardt for providing us with a copy of his pension estimation program.

Retirement Plan Wealth Inequality: Measurement and Trends 
Using Health and Retirement Study (HRS) data linked to administrative data, this study reports trends in the level and inequality of retirement wealth for workers entering the panel aged 51-56 in 1992, 1998, 2004, and 2010. Administrative data are not available for 2016 entrants.

Past measures of retirement wealth have been significantly flawed because of overreliance on self-reports, ignoring information in administrative data, and assuming that retirement plan summary plan descriptions (SPDs) correctly measure plan type. This study resolves conflicts and corrects errors in data interpretation and aims to make the best and most appropriate use of all available information.

In contrast to the Survey of Consumer Finances (SCF) the HRS can be linked to lifetime earnings histories. This study finds that retirement wealth was highly unequally distributed in both 1992 and 2010, with the majority of workers unprepared for retirement in both years. We find evidence of increasing retirement wealth inequality between high and low lifetime earners. Among high earners, retirement wealth to earnings ratios increased at all points on the distribution of wealth to earnings ratios. But among low lifetime earners, retirement wealth to earnings ratios declined for all except the upper tail of the distribution of retirement wealth to earnings ratios.

The second section describes the HRS self-reported data, the linked extracts from W-2 tax records and SPDs, and how previous studies have addressed limitations in the data. The third section reviews the literature on retirement wealth coverage and inequality. The fourth section explains our methodology. The fifth section presents results. Section six presents policy implications and the last section concludes. 


\section{Data}

The HRS self-reported data links to extracts from forms W-2 tax records and SPDs. The HRS provides a pension estimation program (PEP) that enables researchers to calculate retirement wealth from the SPDs.

Self-reported data. The HRS is a nationally representative panel survey of older American households. The first cohort, those born 1931-41 and their spouses of any age, were first interviewed in 1992 when they were ages 51-61. The 1942-47 and 1924-30 birth cohorts were added in 1998, the 1948-53 cohort in 2004, the 1954-59 cohort in 2010, and the 1960-65 cohort in 2016. For participants who gave permission, the 1992-2010 data are linked to extracts from W-2 earnings records. For 1992-2010 participants, HRS staff also attempted to obtain SPDs from multiple sources. To ensure comparability across waves, we focus on employees aged 5156 in 1992, 1998, 2004, and 2010 who first entered the panel in those years and are matched to W-2 earnings records in their current job. This yields samples of 2,035; 592; 859, and 669 workers (See Table 1). We defer to future research analysis of the 1960-65 birth cohort, as these have not yet been linked with SPDs and W-2s.

\section{Table 1 here}

Forms W-2. For participants who consented, the HRS data contains extracts from W-2s for 1978 onwards that can be used to project plan balances, given assumed investment returns and employer contributions. Extracts for 1978 and 1979 are incomplete and are not used in our analysis. The share of workers matched to W-2s varies from 84 percent in 1992 to 39 percent in 2010. Participants are asked repeatedly to give permission to the HRS to link their W-2s. By 2010 almost all 1992 participants have given consent. The share of those consenting to a W-2 link is lower for more recent entrants partly because they have been asked fewer times. W-2s are 
submitted annually by employers to the Internal Revenue Service and contain information on gross pay and elective deferrals. W-2s do not contain Individual Retirement Account (IRA) contributions or balances or DC plan employer contributions, loans, withdrawals or plan balances. W-2s do not exist for the self-employed. The dataset also contains data on selfemployment income but not contributions to retirement plans for the self-employed.

Comparing self-reported DC plan participation with W-2 and other data indicates significant discrepancies, which we attribute to errors in the self-reports. The errors seem to lead to lower-than-expected retirement plan balances. In 1991, only 69 percent of workers with W-2 Box 12 elective deferrals reported a DC plan. Participants who misreport plan type are asked questions about their plan type but the responses aren’t valuable. Average self-reported 401(k) balances in the HRS are lower than reported in provider and other household surveys. The HRS survey design likely contributes to under-reporting (Venti 2011). Errors in self-reported data, even if random, introduce noise, inflate estimates of retirement wealth inequality, and may also bias estimates of trends in retirement wealth inequality if the average size of the errors vary across plan types.

Though well-informed households might provide more accurate estimates of their own plan balances than researchers, we rejected using self-reports for participants who appeared to be well-informed for several reasons. Even people who correctly identify their plan type seem to report inaccurate plan balances because their reported balances cluster at round numbers and often fluctuate from wave to wave by amounts that greatly exceed contributions and plausible investment returns. Although we cannot be certain, because administrative data on plan balances are unavailable, we consider the estimates based on W-2s and assumed investment returns to be superior to self-reported balances. 
But W-2 data have significant limitations. Though information on elective deferrals is contained in Box 12 on the $\mathrm{W}-2$, these data are not available for all participants or years. For years and participants lacking Box 12 data, previous studies have inferred elective deferrals by comparing Box 1, earnings subject to federal income tax, which exclude elective deferrals, with Box 5, Medicare taxable earnings, which includes deferrals. However, Medicare taxable earnings were capped prior to 1994 so that the difference between Box 5 and Box 1 would understate the retirement plan contributions of high earners in those years. In addition, retirement plan contributions were deductible for both income tax and Medicare tax purposes prior to 1984 so that for these years Box 1 equals Box 5. Further, employee contributions to state and local defined benefit plans are also deductible when calculating Box 1 so that a comparison of Box 5 with Box 1 will overstate state and local government workers’ DC contributions.

Previous researchers' solutions to the problem of estimating retirement plan contributions are unsatisfactory when measuring inequality. For example, Dushi and Honig (2010) drop workers with earnings above the Medicare earnings cap. Dropping high earners is reasonable when the goal is to determine the behavior of the broad mass of the population, less so when investigating inequality. Some studies attempt to eliminate state and local government workers from the sample (Cunningham and Engelhardt 2002; Dushi and Honig 2015), a treatment that will bias estimates of retirement wealth inequality, because state and local government workers have relatively generous pensions. Dushi and Honing (2010) includes state and local workers without attempting to adjust the Box 5-Box 1 calculation. We include all workers and adjust the Box 5-Box 1 calculation of those we identify as state and local government workers. We are skeptical the methodology used in previous research to identify likely state and local government 
workers and instead identify them by comparing the Box 5-Box 1 calculation with Box 12 for years for which Box 12 data are available.

SPDs. In order to overcome problems with self-reports, the HRS staff sought to collect SPDs from employers, the Department of Labor, internet searches, and, starting in 2004, by asking employees to locate and submit them. No attempt was made to collect SPDs from individuals who report, sometimes in error, that they are not retirement plan participants. The SPDs summarize rules of DB, DC, stock option, and profit-sharing plans. DB plans require participation, but 401(k)-type plans are voluntary so that a correctly matched DC SPD shows a worker is eligible but not whether they participate.

Self-reports and the SPDs often conflict (see Table 2). ${ }^{1}$ To illustrate the conflict, row three of Table 2 reports that in 1992, of workers who stated they had both DB and DC plans, 27.4 percent were unmatched, 35.3 percent were matched only to a DB SPD, 9.5 percent only to a DC SPD, and 27.8 percent to both DB and DC SPDs.

Table 2 here

The HRS did not collect DC SPDs in 2010; hence, there is no DC match rate in that wave. The HRS data do not distinguish between workers for whom the HRS failed to obtain any SPDs, and workers whose employers stated they did not sponsor a retirement plan. The match rate in earlier years is non-random (Gustman and Steinmeier 2004). The 20.1 percent of workers reporting only a DB plan who were matched to both DB and DC SPDs may be correct because they may be eligible non-participants. Gustman, Steinmeier, and Tabatabai, $(2007,2010)$ attribute mismatches that cannot be explained by eligible workers not participating to worker

\footnotetext{
${ }^{1}$ After excluding workers not matched to SPDs, Table 2 is very close to percentages obtained from an analysis of Gustman, Steinmeier, and Tabatabai (2010) table 7.2A.
} 
mis-reporting. But we question their conclusion. Among individuals reporting only being covered by a DB plan, 21.8 percent have W-2 deferrals, revealing a DC contribution (Table 3). Among individuals matched only to a DB SPD, a larger share, 40.7 percent have $\mathrm{W}-2$ deferrals, reflecting missing DC SPDs, so that the self-report of DB coverage is a superior measure.

\section{Table 3 here}

If we relied solely on the self-reports of workers with a matched SPD, we would incorrectly classify 24 percent of workers who have W-2 deferrals as not having a DC plan. In contrast, if we relied solely on SPDs, we would incorrectly classify 45 percent of workers with W-2 deferrals as not having a DC plan. We conclude that SPDs cannot be relied on to the exclusion of other sources of information.

Pension Estimation Program. The SPDs specify plan rules, benefit formulas, and plan changes. Since they do not contain data on individuals, the HRS created a pension estimation program (PEP) for users to estimate DB and DC wealth by combining SPD data with selfreported data on earnings and deferrals (Rohwedder 2003). The HRS PEP has five significant drawbacks. First, when calculating DC wealth, the user must choose a constant real rate of return, common to all participants - the default rate is 2.9 percent in 2010 - which ignores individual differences in asset allocations and investment returns. Second, the PEP extrapolates a wage history from current year earnings after the user defines the constant rate of real wage growth common to all participants - the default is 1.1 percent a year in 2010. This process will misreport earnings to the extent that current year earnings are mis-reported or earnings growth differs from the assumed rate. Third, the PEP assumes a time-invariant voluntary contribution rate to $401(\mathrm{k})$-type plans equal to the most recent self-reported contribution rate, which overstates the DC wealth of current contributors if participation rates have grown over time or 
workers have taken participation holidays. Even small errors in assumptions can have a dramatic effect on DC wealth estimates (Rohwedder 2003). Fourth, the PEP disregards in-service withdrawals and $401(\mathrm{k})$ loan defaults that amount to perhaps 0.5 percent of $401(\mathrm{k})$ wealth a year, which is significant over a career (Munnell and Webb 2015). Fifth, the PEP does not deduct outstanding loans. Although about 90 percent of active participants can take out DC loans (VanDerhei, Holden, Copeland, and Alonso 2012) and about 18 percent of participants in plans offering loans had a loan outstanding (Vanguard 2014), loans amounted to only 2 percent of plan assets. We proffer the likelihood that loans increase retirement wealth inequality but do not investigate because the HRS survey instrument does not ask about retirement plan loans.

To correct the first three problems and coding anomalies, Cunningham, Engelhardt, and Kumar (2007) (CEK) created their own PEP to estimate DC wealth for 1992 and 1998. Their PEP uses W-2 data on earnings and elective deferrals; uses the plan adoption and amendment dates indicated in the SPD to determine a person's eligibility for certain plan features; and incorporates a user-defined time-varying rate of return. Convinced by CEK’s findings that the HRS PEP systematically overstates DC wealth, we use their methods.

The HRS PEP calculates the expected present value of DB wealth - DB benefits are typically a function of current or recent salary, age, and years of service - by combining selfreported data with plan rules obtained from the SPDs, and assumed mortality and interest rates. Wealth is discounted back to the present and we prorate between past and anticipated future service. The HRS PEP allows calculating DB wealth with normal or early retirement formulas within a user-defined age range. These calculations introduce the following measurement errors. First, reporting errors in self-reported earnings will be reflected in DB wealth estimates. Second, older workers often experience earnings declines (Rohwedder 2003), whereas the HRS PEP 
assumes a constant rate of real wage growth right up to retirement. As benefits are typically based on final salary or the average of the last few years' salary, the HRS PEP probably overstates DB wealth, except for those near retirement. ${ }^{2}$ Third, the HRS PEP does not incorporate the risk of premature job-separation, which can substantially reduce DB wealth. Almost half of workers retire before they expect (Munnell, Sanzenbacher, and Rutledge 2015).

We replace self-reported earnings data with $\mathrm{W}$-2 data. While modelling wage trajectories and the risk of premature job-separation of DB participants is beyond the scope of this study, we instead make ad-hoc adjustments for risk by discounting future benefits at the corporate bond interest rate rather than at the risk-free Treasury bond interest rate.

For 2010, the HRS PEP allows researchers to impute DB wealth to workers without DB SPDs. Using this option, Fang, Brown, and Weir (2016) assign DB coverage to all workers either matched to a DB SPD or who self-report DB coverage. Their approach will overstate total DB coverage when workers covered only by DC plans misreport being covered by a DB plan.

\section{Previous literature on retirement plan coverage and wealth inequality}

Previous retirement wealth studies focus on coverage, contribution rates and asset allocations, retirement wealth, and comparing wealth accumulation under DB and DC regimes.

Studies of coverage. Self-reported data from the Current Population Survey (CPS) reveal that only about 50 percent of full time private sector workers participate in a retirement plan at

\footnotetext{
${ }^{2}$ We assume that the Rohwedder (2003) calculations are conditional on labor market participation but not conditional on remaining with the same employer.
} 
any point in time, with the participation rate trending down (Munnell and Bleckman 2014). ${ }^{3}$ Workers move in and out of coverage, so the share ever covered is higher. Lower-income workers are less likely to participate, with the socioeconomic pension coverage gap mainly reflecting lower eligibility rates among low earners (Karamcheva and Sanzenbacher 2010; Wu and Rutledge 2014).

An alternative approach to relying solely on self-reported data, designed to address misand under-reporting, is to combine self-reported data with data from W-2s (Dushi, Iams, and Lichenstein 2011). But workers who report participating in a DC plan but do not have W-2 deferrals could have a DC plan that does not require employee contributions, could have mistakenly reported their DB plan as DC, or could have no retirement plan coverage. Assuming they have no retirement plan coverage yields coverage rates in line with self-reported data, whereas assuming they are participating in some other plan type yields higher coverage rates. We conclude the CPS data represent a lower bound to a range of coverage estimates.

Another approach is to rely solely on IRS Statistics of Income data, classifying workers as covered if retirement plan elective deferrals are shown in Box 12 of the W-2 or if Box 13 has been ticked, indicating active participation in any type of retirement plan (Brady 2017). These data show a participation rate that is consistently 4-6 percentage points higher than the comparable CPS participation rate. ${ }^{4}$ Box 13 is not included in the HRS W-2 dataset and we therefore cannot use their approach.

3 The Current Population Survey question changed in 2014, so that post-2013 coverage is not comparable with coverage in previous years.

4 The study headline participation rate of 77 percent is obtained by focusing solely on a highly select group - workers ages 45-64 with an Adjusted Gross Income of \$30,000 or more. 
Studies of contribution rates and asset allocations. Conditional on participation, the average DC employee contribution rate is 6.5 percent of salary (Brady 2017). Contribution rates are higher for older workers, but vary little with earnings. High earners and younger workers are more likely to hold equities but differences in mean equity shares are modest. The mean share in company stock declined from 11 percent in 2007 to 6 percent in 2016 and there is substantial individual-level heterogeneity in investment allocations, with significant shares of participants with equity allocations of zero or 100 percent (VanDerhei, Holden, Copland, and Bass 2018). As equity returns have exceeded those on bonds, differences in asset allocation likely contribute to inequality.

Conditional on the employee participating, higher earners receive larger employer matches as a percent of salary (Saad-Lessler, Ghilarducci, and Resnik 2018). Given that employee contribution rates vary little with earnings; this likely reflects differences in the generosity of match formulas.

Studies of Retirement Wealth. Studies of retirement wealth (IRA, DB, and DC wealth, excluding the expected present value of anticipated Social Security benefits) typically use Survey of Consumer Finances (SCF), Survey of Income and Program Participation (SIPP), and HRS data. We do not regard the HRS age restriction as a significant drawback because we measure the distribution of retirement wealth of households approaching retirement. The Current Population Survey (CPS) asks about retirement plan coverage but not wealth. The SCF contains a high-wealth sub-sample to investigate the upper tail of the wealth distribution, but the lack of either a panel or a link to administrative data makes it unsuitable for describing the relationship 
between retirement wealth and lifetime earnings. ${ }^{5}$ And the SCF likely suffers from the same level of misreporting of pension type as the HRS does.

Two consistent findings emerge. First, retirement wealth is highly unequally distributed, although less unequally distributed than non-retirement financial wealth (Wolff 2015; DevlinFoltz, Henriques, and Sabelhaus 2015a, 2015b). Using 2014 SIPP data and a broader sample, Ghilarducci, Papadopoulos, and Webb (2017) report that one third of workers nearing retirement have no retirement wealth. A 2014 Government Accountability Office study reports that the one percent of IRA holders with balances in excess of \$1 million hold 22 percent of IRA wealth. Retirement wealth is also more unequally distributed than current period earnings (Mitchell and Moore 1997) and total wealth varies enormously even within lifetime earnings deciles (Venti and Wise 1998).

Second, although DC wealth was substantially more unequally distributed than DB wealth in all years, the displacement of DB by DC plans has not been associated with a significant increase in retirement wealth inequality (Wolff 2015; Devlin-Foltz, Henriques, and Sabelhaus 2015a, 2015b; Munnell, Hou, Webb, and Li 2016).

Although higher-income earners have lower replacement rate targets, their lower Social Security replacement rates mean they need to accumulate larger multiples of their earnings. Including Social Security wealth, the ratios of mean and median retirement wealth to earnings

${ }^{5}$ Towards the end of the SCF interview, after detailed income components have been summed to arrive at a total, respondents are asked if that total income is higher than, lower than, or about the same as their income in a "usual” year. Most respondents say their reported income is in fact about normal. But our analysis of HRS data indicates only a modest correlation between current and lifetime income. 
vary little by lifetime earnings decile. The ratio of DC wealth to lifetime earnings is higher in the upper lifetime earnings deciles; whereas the ratio of DB wealth to lifetime earnings is lower (Poterba, Venti, and Wise 2007, using 2000 HRS data). But this pattern masks enormous differences in wealth, conditional on lifetime earnings (Venti and Wise 1998, using 1992 HRS data and focusing on total wealth excluding Social security and financial wealth excluding retirement accounts). Most wealth inequality stems from differences in outcomes within lifetime earnings groups.

The study most similar to ours is Munnell, Hou, Webb, and Li (2016), who analyzed household HRS data from 1992, 1998, 2004, and 2010 and sorted households by quartile of educational attainment (not lifetime earnings), relied solely on the self-reported data, and did not examine the distribution of wealth within quartiles. They found, consistent with previous research, that DC wealth was more skewed towards the top quartile of educational attainment than DB wealth, but that the distribution of total retirement wealth by education quartile barely changed over the 18-year period, notwithstanding the displacement of DB by DC wealth.

Comparing wealth accumulation under DB and DC plans. DC wealth of pre-retirees falls far short of DB wealth (Munnell, Hou, Webb, and Li 2016; Ghilarducci, Papadopoulos, and Webb 2017). Some of the disparity likely reflects the immaturity of the DC system - older workers have not had a lifetime of exposure. But leakages, high fees, and portfolios not located on the efficient market frontier also contribute to the failure of DC plans to live up to their promise (Munnell and Webb 2015; Tang, Mitchell, Mottola, and Utkus 2010), as does nonparticipation by eligible workers.

In contrast, a well-functioning DC system might engender greater wealth accumulation than a DB system, because job-changers are not penalized. Using HRS data on 
earnings histories and job-separations, Poterba, Rauh, Venti, and Wise (2006) compare retirement wealth in DB and DC plans. They randomly assign participants first a DB plan and then a DC plan. They assume that vested DB participants receive a deferred pension on jobseparation based on their salary at the date of separation. The DC simulations assume zero leakages, and zero non-participation. They find that even in risk-adjusted terms, DC plans almost always dominate private sector DB plans.

Poterba, Rauh, Venti, and Wise (2006) will likely understate DC wealth inequality because in addition to assuming zero leakages and 100 percent participation they also assume all participants earn the same investment returns. Even with these restrictive assumptions, they find that DC plans produce greater inequality (as measured by the ratio of the $90^{\text {th }}$ to the $50^{\text {th }}$ percentile of the wealth distribution) than DB plans.

More generally, those approaching retirement in 1992 were not living in a "golden age" of pensions, due to patchy DB coverage and erosion of benefits by inflation and pre-retirement job-loss (Kolodrubetz and Landay 1973). In addition, low earners get lower benefits from “integrated” DB plans - employers count Social Security benefits as part of the total benefit, which can also foster between-group inequality.

\section{Methodology}

We define retirement wealth as the sum of DB and DC wealth from current and past jobs, including profit sharing and money purchase plans, and IRA wealth. We focus on individuals, not households, to permit a straightforward categorization of plan type and to avoid the complications associated with household formation and dissolution. We use only individuals matched to W-2s and reweight by the inverse of the probability of a W-2 match. 
Money is fungible, and households can tap non-retirement financial wealth and nonfinancial wealth to fund post-retirement consumption. DC wealth may be a better substitute than DB wealth for taxable financial assets in the household's portfolio. As the wealthy are more likely to hold significant non-retirement financial wealth, asset relocation in a mostly DC system may contribute to increases in retirement wealth inequality. Households may also offset DC wealth accumulation with mortgage borrowing (Engen and Gale 1997). We defer a study of the above issues to future research.

We include all tax-deferred and tax-advantaged accounts that appear to be designed for retirement savings, as well as the expected present value of DB pensions. Thus, we include profit sharing plans, but exclude health savings accounts, even though they are a tax efficient means of saving money to cover post-retirement health care costs.

DB wealth from current job. We use the HRS PEP to calculate the expected present value of current job DB wealth for plans for which DB SPDs are available. We consider the W-2 earnings data more reliable that self-reported data and therefore modify the HRS PEP to calculate DB wealth using W-2 earnings data. We discount at the AAA corporate bond interest rate $(7.92 \%$ in $1992,6.40 \%$ in $1998,5.46 \%$ in 2004 , and $4.53 \%$ in 2010$)$ and pro-rate to past service. Friedberg and Webb (2005) show employees' retirement timing decisions are influenced by DB wealth accrual. We assume employees retire when first eligible for normal retirement benefits, an age at which the expected present value of benefits often peaks. We did not use a constant interest rate across years because we want to preserve within-wave comparability with DC wealth, the value of which reflects prevailing interest rates. We use the HRS PEP default real wage growth assumptions of 0.96 to 1.1 percent a year to retirement. 
We assume no DB SPDs were erroneously matched and that if the HRS matched a DC plan, which indicates the HRS successfully identified and contacted the employer, but did not match a DB plan, the worker is not covered by a DB plan, regardless of self-reported plan type. We impute DB coverage for those without any SPDs using a donor pool of those matched to any SPDs and a comprehensive set of covariates that include self-reported plan type and characteristics associated with a SPD match. Importantly, to create an appropriate joint distribution of DB and DC coverage, the set of covariates includes a variable indicating whether the worker made $\mathrm{W}$-2 elective deferrals.

Our approach will likely create an upward bias to DB coverage because those with DB SPDs are more likely to have DB plans than those without (conditioning on covariates). ${ }^{6}$ We adjust the coverage rate by recoding as DC those who report being covered only by a DC plan and have W-2 elective deferrals. After this adjustment, we obtain an overall DB coverage rate that matches that observed in the self-reported data, although the identities of covered workers differ.

DB wealth from past jobs. While some SPDs from previous jobs are available for the 1992 and 1998 waves, the HRS did not collect SPDs for past jobs in 2004 and 2010. The match rate is low - in 1992, only 26 percent of workers reporting that they anticipated future benefits from a DB plan from a past job were matched to an SPD. We therefore use Gustman, Steinmeier,

${ }^{6}$ In some cases, the absence of an SPD reflects the inability of the HRS staff to contact or obtain information from the employers. In other cases, the employer might have informed the HRS that they did not sponsor any retirement plans for employees of the relevant class, in which case the true but unobserved probability of DB coverage will be zero. This categorization was not retained by the HRS. 
and Tabatabai (2014) estimates of DB wealth from past jobs, including DB pensions in payment, based on self-reported data. In 1992, only 9.4 percent of workers had DB wealth from past jobs (including DB pensions in payment) so that any errors in self-reported data will have only a modest effect on total retirement wealth.

DC wealth from current jobs. To calculate current job DC wealth resulting from employee contributions, we combine $\mathrm{W}-2$ data on gross pay and elective deferrals with selfreported data on hire date and DC plan asset allocation and Ibbotson (2018) data on market returns by asset class.

We rely on W-2 Box 12 data, where available. For workers for whom Box 12 data are available for 1991 onwards, we estimate pre-1991 deferrals by comparing the 1991 Box 12 entry with the 1991 difference between Box 5 and Box 1. If Box 12 equals zero, we assume the difference between Box 5 and Box 1 in all previous years represents employee DB contributions. If Box 12 equals Box 5 minus Box 1, we assume the difference between Box 5 and Box 1 represents DC elective deferrals. In all other cases, we make an apportionment. We experimented with using SPDs to identify employee contributions to DB plans, but found that this approach could only explain a small part of the difference between Box 12 and Box 5 minus Box $1 .^{7}$

The Box 5 minus Box 1 calculation cannot be applied prior to 1984 because Social Security and Medicare taxes were calculated on earnings net of elective deferrals. We assume zero employee contributions in 1981 and linearly interpolate coverage rates between 1981 and 1984, the first year for which data are available. For workers with earnings above the taxable

\footnotetext{
${ }^{7}$ Cunningham and Engelhardt (2002) identified voluntary contributions by comparing mandatory contributions specified in the SPD with the difference between Box 5 and Box 1. We believe their approach overstates voluntary contributions.
} 
maximum in any of the years 1984 to 1990 or 1991, we impute iteratively, working back from the most recent year, using data from time $t+1$ to impute time $t$ to capture serial correlation in deferrals.

For workers for whom Box 12 data were never collected, we impute employee contributions using Box 5 and Box 1 data from a donor pool of workers whose DC contributions were based on the methodology described above. After taking into account the $\mathrm{W}-2$ data, the SPDs and self-reported data contain almost no additional information on employee contributions and are not used.

For employer contributions, we considered and rejected using matched or imputed SPDs. The DC SPD match rate is low in earlier years and likely biased in favor of larger plans, and DC SPDs were not collected in 2010, which means DC wealth for that wave must be constructed solely from self-reports. Also, DC plan type - profit sharing, money purchase, 401(k), etc. needed to impute SPDs, is often missing and likely misreported.

We use a worker being matched to a DC SPD as one indicator of a worker having a DC plan, regardless of what a worker self-reported as their plan type. But we don't use SPD information to calculate DC wealth from employer contributions. Instead, we use self-reported data to calculate employer DC contributions.

To provide consistency with actual and imputed data, we impute employer contributions to DC plans for workers who did not report employer contributions, but may have them. These workers include those who 1) say they have a DB plan but are not assigned a DB plan, or are matched to a DC SPD, 2) don't have W-2 contributions, are not assigned a DB plan, and report no employer contribution, and 3) those who say they have a DC plan but don't answer the subsequent questions. 
DC wealth from past jobs and IRA wealth. When workers leave their jobs they can withdraw their 401(k) plan balance, roll the money into an IRA, leave the money invested in the old plan, or, more rarely, move their 401(k) into a new employer’s 401(k). (Very few choose multiple options [Vanguard 2014]). HRS participants are asked how much was in their account when they left their employer, which of the above options they chose, and if they rolled over the balance into an IRA or left it in the original plan, how much is in the account now.

The HRS collected DC SPDs for some previous jobs. We choose not to use W-2s and SPDs to calculate current wealth from past jobs for two reasons. First, significant leakages and transfers likely occur not only at job separation but also after they get a new job. Second, most DC wealth is now held in IRAs, not in 401(k)s (Munnell and Webb 2015), especially among older workers who have changed jobs several times during their career. These IRAs commingle rollovers from possibly several past jobs with direct contributions. Using W-2 and SPD data to estimate current wealth from past jobs would create a new issue - how to calculate the share of the IRA balance that related to that past job. We consider that, even with reporting error, the selfreported current account balance will generally be a more accurate measure of current DC wealth from past jobs than calculations based on SPDs and W-2s. We therefore use imputed values of IRA wealth from the RAND HRS Longitudinal File. We use Gustman, Steinmeier, and Tabatabai (2014) data constructed using self-reported data on DC wealth from previous jobs, not rolled over to IRAs.

DC investment returns. In 1992, 1998, and 2004, participants in 401(k) type plans report whether the money in each of their accounts is invested mostly in stocks, mostly in interest earning assets, or is about evenly split. In 2010, they are asked to report the percentages invested in stocks. We impute missing asset allocations for 2010. For 1992, 1998, and 2004, we 
considered but rejected assuming that individuals giving the same response to the asset allocation question had the same asset allocation, because this assumption would suppress heterogeneity in asset allocations and thus in investment returns. Instead, we imputed asset allocations by randomly drawing from the 2010 allocations lying in the range zero to 40 percent stocks for those who reported they were mostly in bonds in their primary DC plan, the range 40-60 percent for those who reported they were about evenly split, and 60-100 percent for those who reported they were mostly in stocks. Data on changes in investment allocations are only available for 2004 and 2010. To ensure consistency in treatment across waves, we further assume that participants never changed their asset allocations and that they rebalanced annually. We do not attempt to introduce heterogeneity in investment returns, conditional on asset allocation, because we lack data on the individual funds in the accounts.

Assigning lifetime earnings quintiles. Detailed records of earnings from employment and self-employment are available from 1978, but those for 1978 and 1979 are incomplete. Summary earnings are available from 1951, but these later data are capped at Social Security maximum taxable earnings. In the 1970s, up to 37 percent of workers earned in excess of the maximum in any year (Fang, Brown, and Weir 2016). To ensure comparability between 1992, 1998, 2004, and 2010, we use the last 12 years' CPI-indexed earnings as our denominator, 19801991 for 1992, 1986-1997 for 1998, and so on. We rejected imputing earnings above the maximum, assessing that the estimation errors associated with the imputation process and loss of consistency between waves would more than outweigh the benefit of including earnings at younger ages in the average.

Theil calculations. The Theil index is defined as follows: 
Theil $_{t}=\frac{1}{n_{t}} \sum_{i=1}^{n_{t}}\left(\frac{\text { wealth }\left(i_{t}\right)}{m_{t}} \log \left(\frac{\text { wealth }(i)_{t}}{m_{t}}\right)\right)$

where wealth $(i)_{t}$ is the wealth of worker $i$ at year $t, n_{t}$ is the total number of workers in year

$t$, and $m_{t}$ is the average wealth of all workers in year $t$. We recode the log of zero as zero. The Theil index is one of a family of generalized entropy (GE) measures. Other GE measures avoid using logarithms, but are excessively sensitive to the upper part of the wealth distribution and to the presence or absence of large wealth-holders in particular years.

The Theil index has the advantage over the Gini coefficient of being additive across different subgroups in the population, that is, the Theil index of overall wealth dispersion can be decomposed in the between-group and within-group components of dispersion. Dispersion between-groups equals total dispersion, Theil $_{t}$ minus within-groups dispersion, $D w i n_{t}$.

The within earnings group dispersion of wealth for the Theil index for year $t$ is defined as follows:

$$
\operatorname{Dwin}_{t}=\sum_{c=1}^{n_{c}}\left[\frac{m_{c, t} n_{c, t}}{m_{t} n_{t}}\right] \text { Theil }_{c, t}
$$

where $m_{c, t}$ is the average wealth of earnings group $c$ at time $t$ and $n_{c, t}$ is the number of individuals in earnings group $c$ at time $t$.

Although the Theil coefficient takes the value zero when there is perfect equality, it otherwise lacks the straightforward representation of the Gini coefficient. It also suffers from the disadvantage of the Gini coefficient in that it does not indicate where dispersion occurs within the distribution. Therefore, we rely on tabulations of selected percentiles of relevant distributions for much of our analysis. 


\section{Results}

Our first key finding is that the top earnings quintile holds half of all retirement wealth, a share that is almost unchanged from 1992 to 2010 (Table 4). The bottom quintile has barely one percent of the total.

\section{Table 4 here}

Our second key finding is that retirement wealth inequality mainly reflects the common plight of low to moderate earners with very little retirement wealth, not the outsize accumulations of the few. Among workers aged 51-56 in 2010 - the first group to spend their careers in a mostly DC system - 18.6 percent had no retirement wealth, almost unchanged from the 17.5 percent in 1992 (Table 5).

\section{Table 5 here}

Workers in lower earnings quintiles are more likely to have no retirement wealth. In 2010, 51.2 percent of bottom quintile workers had zero retirement wealth, compared with 2.2 percent of top quintile workers. In the bottom quintile, the share of workers with no retirement wealth increased from 45.4 percent to 51.2 percent between 1992 and 2010, indicative of a strengthening of the correlation between lifetime earnings and retirement plan coverage.

This divergence in wealth accumulation between earnings quintiles is reflected across the percentiles of the wealth distribution. In 2010, median retirement wealth in 2010 dollars was $\$ 294,700$ in the top earnings quintile, up from $\$ 175,500$ in 1992. But 2010 median retirement wealth was zero in the bottom earnings quintile, down from $\$ 1,900$ in 1992. Corresponding numbers for the $75^{\text {th }}$ percentile of the wealth distribution are $\$ 505,400$ (2010) and $\$ 315,100$ (1992) for the top earnings quintile and \$7,800 (2010) and \$18,700 (1992) for the bottom. Except among high earners, wealth is in general no higher in 2010 than in 1998, a sobering finding 
given that people are living longer, post-retirement health care costs are rising, lifetime earnings are generally increasing, and financial returns are generally lower. The question arises: are wealth accumulations adequate? One approach to determining the adequacy of retirement savings is to compare accumulations with the amounts households would have accumulated had they chosen an "optimal” savings plan such that the marginal utility of current consumption equaled the expected discounted marginal utilities of consumption in each subsequent period. Those who experience economic misfortune may nonetheless suffer a decline in living standards in retirement even though they saved optimally. An example of this type of analysis is Scholz, Seshadri, and Khitatrakun (2006). An alternative way to determine retirement wealth adequacy is to construct a simple spreadsheet-based life-cycle model that abstracts from risk and calculates the wealth required to maintain pre-retirement living standards (Skinner 2007; Munnell, Hou, and Sanzenbacher 2016; Fidelity 2018). The results obtained with a spreadsheet are highly sensitive to assumptions regarding the age of retirement, investment returns, home ownership, health care costs, etc. Older households should have larger wealth to earnings ratios because they have fewer remaining years to contribute to retirement plans and earn investment returns and higher earners should have larger wealth to earnings ratios because they will receive lower Social Security replacement rates. Fidelity (2018) proposes target wealth to income ratios of six at age 50, seven at age 55, and ten at age 67, whereas Skinner (2007) proposes lower ratios at retirement that would imply substantially lower target wealth to earnings ratios at younger ages.

Table 6 reports selected percentiles of the distribution of the ratio of total retirement wealth to earnings, by earnings quintile, in 1992, 1998, 2004, and 2010. Median wealth to earnings ratios range from zero in the bottom earnings quintile to 2.43 in the top earnings quintile in 2010. While acknowledging the considerable heterogeneity in preferences, 
circumstances, and ages in our sample - as well as our focus on individuals, not households we consider it unlikely that most workers have adequate retirement wealth.

\section{Table 6 here}

We also compare wealth accumulations with the amounts that workers aged 51-56 in 2010 would have accumulated under a well-functioning DC system. We assume all workers had contributed six percent of salary with a 50 percent employer match to a 50:50 stock/bond fund. Median retirement wealth for the top lifetime earnings quintile would have been 2.7 times that observed in the data $(\$ 769,800$ vs. $\$ 294,700)$. The median in the bottom lifetime earnings quintile would have been $\$ 154,200$, compared with the zero wealth they have now. Median retirement wealth of older workers would have been $\$ 417,000$ rather than $\$ 67,000$, so that the median worker falls 84 percent short.

Some households accumulate extremely large retirement account balances, not only by thrift or good fortune, but also by investing in high return asset classes such as private equity that are unavailable to most investors (GAO 2014). Our sample size is insufficient to make meaningful statements about the upper tail of the retirement wealth distribution and our methodology will also likely understate account balances in the tail because it assumes market returns. Instead, we rely on the GAO study, while acknowledging that it also understates wealth in the tail because it includes only IRA wealth, not 401(k) or DB wealth. Our analysis of the GAO study show that only 0.02 percent of IRA holders have balances in excess of \$5 million, and these accounts contain only 2.7 percent of all IRA dollars. Thus, these very large accounts have a negligible effect on overall retirement wealth inequality, although they represent an abuse of retirement tax exemptions which are intended to encourage saving for retirement, not dynastic wealth accumulation. 
Our third key finding is that, surprisingly, retirement wealth inequality, as measured by the Theil index, has not increased significantly between 1992 and 2010, among either those with some retirement wealth or all workers. Although DC wealth is more unequally distributed than DB wealth in each wave, neither the difference between DB and DC inequality nor the shift away from DB to DC wealth for these cohorts been large enough to substantially increase inequality among workers with retirement wealth. Nor has the decline in lifetime retirement plan coverage been large enough to increase retirement wealth inequality among all workers.

Inequality is lowest among workers with both a DB and DC plan and highest among workers with just a DC plan (See Table 7). In 1992, the Theil indices for DC only, DB only, and both DB and DC wealth were $0.703,0.623$, and 0.438 , and in $2001,0.724,0.583$, and 0.381 . Inequality was greater for all workers than for workers with retirement wealth, reflecting the inclusion of zeros in the former measure. In 1992, the Theil indices of retirement wealth inequality for all workers and all workers with retirement wealth were 0.794 and 0.602 , and in 2010, 0.819 and 0.613 .

We acknowledge the limitations of using a single number, the Theil index, to characterize an entire distribution. The Theil might place excessive weight on holders of very small account balances that are economically not very significant, even for the account holders. We are reassured our interpretations are correct because we obtain similar results with the Gini index, a GE(0) index which places greater emphasis on the bottom of the wealth distribution and a GE(2) index which places greater emphasis on the top of the wealth distribution.

\section{Table 7 here}

We report coverage trends because it helps us understand why the Theil index of retirement wealth inequality has not changed much. Table 8 reports the shares of workers with 
DB (with or without DC), DC (with or without DB), both DB and DC, or any retirement wealth from their current job (upper panel) and current or past job (lower panel). The share with DB plans from a current or past job declined by 9.8 percentage points, from 57.1 to 47.3 percent, and the share with DC plans increased by 4.2 percentage points, from 66.5 to 70.7 percent. Offsetting these trends, the share of workers with both DB and DC plans decreased by 4.7 percentage points, from 40.9 to 36.2 percent. These changes were not large enough to increase overall retirement wealth inequality, given the small difference between DB and DC wealth inequality.

Table 8 here

Our fourth key finding is that among holders of retirement wealth, retirement wealth inequality within earnings quintiles substantially exceeds inequality between quintiles. Table 9 includes respondents with no retirement wealth, unlike Table 6 results, and reports selected percentiles of wealth to earnings ratios, by earnings quintile for each wave.

\section{Table 9 here}

In 1992, the $90^{\text {th }}$ percentile of the wealth to earnings ratio within each earnings quintile was ten to twenty times the $10^{\text {th }}$ percentile. In the bottom earnings quintile, the wealth to earnings ratio was 4.91 at the $90^{\text {th }}$ percentile compared with 0.25 at the $10^{\text {th }}$ percentile. In the top earnings quintile, the corresponding ratios were 5.18 and 0.57 . In contrast, wealth to earnings ratios varied little between earnings quintiles particularly in the upper part of the wealth distribution. The $90^{\text {th }}$ percentiles of the top and bottom earnings quintiles had almost identical wealth to earnings ratios of 5.18 and 4.92, respectively (the $75^{\text {th }}$ percentiles were 3.42 and 3.08 respectively). Theil indices for wealth to earnings ratios of individuals with any retirement wealth similarly show that most inequality reflects inequality within earnings quintiles. In 2010, 
total inequality was 0.426 , comprising "within quintile inequality" of 0.374 and "between quintile inequality” of 0.052 .

Our fifth key finding is that the Theil index of inequality hides increasing disparities in wealth accumulation between high and low earners. Between 1992 and 2010, wealth to earnings ratios increased for workers in the top earnings quintile at all points in the wealth distribution, and decreased at all points of the wealth distribution for those in the bottom quintile of the earnings distribution. Thus, in the top earnings quintile, the $10^{\text {th }}$ percentile of the wealth distribution increased from 0.48 to 0.83 times earnings, the median from 2.01 to 2,54 times earnings, and the $90^{\text {th }}$ percentile from 5.09 to 8.24 times earnings (Table 9). Although wealth to earnings ratios approximately doubled across the distribution, the size of the increase was, of course, much greater at the top of the distribution. In contrast, in the bottom earnings quintile, the $10^{\text {th }}$ percentile of the wealth to earnings ratio declined from 0.26 to 0.04 , at the median from 1.42 to 0.46 , and at the $90^{\text {th }}$ percentile from 5.86 to 3.80 .

The increase in inequality in the bottom quintile does not reflect an increase in participation, so that workers who previously had nothing now have something. In fact, the share with no retirement wealth increased from 45.5 percent in 1992 to 51.2 percent in 2010. To interpret the increase in wealth to lifetime earnings ratios at the top of the wealth distribution of the top earnings quintile and decrease in wealth to lifetime earnings ratios of the bottom earnings quintile, we posit that it results from differences in capacity to navigate an ever more individualized retirement savings system.

However, the question then arises: if low earners have fared badly relative to high earners, why has the Theil index of overall retirement wealth inequality not increased among retirement plan participants between 1992 and 2010? A decomposition of the 1992 and 2010 
Theil indices for workers with any retirement wealth of 0.602 and 0.613 reported in Table 7 reveals that an increase in between-group inequality from 0.231 to 0.367 was offset by a decrease in within-group inequality from 0.371 to 0.346 But the within-group inequality measure aggregates inequality within all groups, placing greater weight on inequality in higher earnings quintiles because of their greater wealth. When we calculate Theil inequality measures within earnings quintiles, we find that inequality in the bottom earnings quintile increased from 1.203 in 1992 to 1.410 in 2010. In contrast, wealth inequality in the top quintile declined from 0.423 in 1992 to 0.315 in 2010 (Table 10). Consistent with the tabulations of selected percentiles of the wealth distribution, the Theil index shows increases in inequality both within the bottom earnings quintile and between earnings quintiles. However, these increases are offset by decreasing inequality within the top earnings quintile.

Table 10 here

\section{Discussion}

Adequacy of retirement savings. The policy concern is that households will have insufficient resources to maintain their standard of living in retirement, (GAO 2016; Munnell, Hou, and Webb 2014). ${ }^{8}$ Of social and political importance is that one third to one half of middle class older workers will descend from the middle class to near poverty in old age (Ghilarducci, Papadopoulos, and Webb 2018).

\footnotetext{
8 According to the life cycle model, households should smooth the expected marginal utility of consumption. Households may behave optimally yet experience declines in consumption in retirement as a result of bad financial or labor market realizations.
} 
We found enormous variations in retirement wealth accumulation among workers with similar lifetime earnings. We interpret these variations not as resulting from differences in preferences, but as the outcome of a retirement system that fails to work even for higher earners. Thus, although only 2.2\% of employees age 51-56 in 2010 in the top quintile did not have any retirement wealth in their current and past jobs, almost a quarter of households in the top earnings decile will be unable to maintain their standard of living if they retire at age 65 (Munnell, Orlova, and Webb 2013).

Policy options include mandating retirement savings plans (Ghilarducci and James, 2018), taking steps to lower fees, allowing people to make additional Social Security contributions (Ghilarducci, Papadopoulos, Sun, and Webb 2018), eliminating or reducing opportunities for pre-retirement withdrawals, and providing refundable tax credits or low-income savers credits. Although financial education can help some workers (Lusardi, Michaud, and Mitchell 2017), it must overcome strong behavioral biases (Laibson 1997) and it may be more effective to change the system to accommodate the workers we have rather than to attempt to change the workers to accommodate the current system.

We defer to further research an investigation of between-cohort inequalities. Provided benefit formulas are not changed, DB plans provide all cohorts with similar replacement rates, although cohorts may suffer differentially from the effects of inflation. In contrast, differences in lifetime investment returns can result in different birth cohorts retiring with substantially different DC account balances (Cannon and Tonks 2004), although low account balances may be somewhat offset if the declines in asset prices reflect increases in risk premia, increasing anticipated returns and thus sustainable drawdown rates. 
Use of pension data in econometric models. The use of inaccurate data on retirement wealth and retirement plan coverage may bias estimates of the impact of retirement wealth and wealth accrual on the retirement decision. To illustrate, Chan and Stevens (2004) use SPDs to determine whether workers are well informed about the retirement incentives they face and report differences in behavior between the well informed and those they presume to be misinformed. But use of SPDs may result in workers being incorrectly assigned to the two groups.

\section{Conclusion}

Before commencing this study, we had hypothesized that the displacement of DB by DC plans over the period 1992-2010 would have been associated with increases in between-group retirement wealth inequality. Low and moderate earners are more exposed to economic shocks, causing more pre-retirement withdrawals and gaps in coverage (Ghilarducci, Radpour, and Webb 2019); are less well-equipped to make complex financial decisions required of DC participants (Lusardi and Mitchell 2013); have lower employer matches (Ghilarducci, Saad-Lessler, and Reznik 2018); and invest more conservatively (Agnew, Balduzzi, and Sunden 2003).

We were uncertain whether the shift to DC would be associated with an increase in retirement wealth inequality within earnings quintiles. On one hand, the shift to DC plans may have boosted within-earnings-group inequality because people with the same earnings differ in their preferences, willingness to participate (Clark, Maki, and Sandler Morrill 2014), investment returns, economic shocks, and financial literacy, factors that affect DC but not DB wealth accumulation. On the other hand, the switch to DC may reduce within-group inequality if DC plans help workers with low job tenures accumulate wealth better than DB plans that require 
vesting periods. But most DC plans impose a waiting period before workers are eligible for a match or even to participate so that job changers often have significant gaps in accumulation (GAO 2016).

We found that Theil indices of overall retirement wealth inequality was little changed over the period 1992-2010 even though DC wealth is more unequally held than DB wealth. In part, this reflected already high levels of inequality in 1992 - with the top quintile of lifetime earners holding half the wealth and striking levels of inequality within that group. Workers approaching retirement in 1992 had spent their careers in a mostly DB system. For many at all earnings levels, it was a not a golden age. But the lack of a significant increase in inequality, as measured by the Theil index, also reflects the fact that even in 2010, many older workers were still covered by DB plans from a current or past job.

We acknowledge the limitations of the Theil index. It may place excessive weight on wealth differences at the bottom of the wealth distribution that may not be financially significant even for low lifetime earners. The Theil index also does not tell us where in the distribution the inequality is occurring. Therefore, we also tabulated selected retirement wealth percentiles by lifetime earnings group. These tabulations reveal a more disturbing story - that high lifetime earners were faring substantially better in 2010 than in 1992, whereas most low earners were faring worse. 


\section{References}

Agnew, Julie, Pierluigi Balduzzi, and Annika Sunden (2003). “Portfolio Choice and Trading in a Large 401(K) Plan.” American Economic Review, 93(1): 193-215.

Brady, Peter J. (2017). "Who Participates in Retirement Plans.” ICI Research Perspective 23(5). www.ici.org/pdf/ per23-05.pdf.

Cannon, Edmund and Ian Tonks (2004). “U.K. Annuity Rates, Money’s Worth and Pension Replacement Ratios 1957-2002.” Geneva Papers on Risk and Insurance: Issues and Practice, 29(3): 371-393

Chan, Sewin, and Ann-Huff Stevens (2004). “What You Don’t Know Can’t Help You: Pension Knowledge and Retirement Decision Making.” The Review of Economics and Statistics, 90(2): 253-266.

Clark, Robert L., Jennifer A. Maki and Melinda Sandler Morrill (2014). “Can Simple Informational Nudges Increase Employee Participation in a 401(k) Plan?” Southern Economic Journal, 80(3): 677-701.

Cunningham, Christopher R. and Gary V. Engelhardt (2002). “Federal Tax Policy, Employer Matching, and 401(k) Saving: Evidence from HRS W-2 Records.” National Tax Journal, 45(3): 617-645.

Cunningham, Christopher R., Gary V. Engelhardt, and Anil Kumar (2007). “Measuring Pension Wealth,” in Madrian, Brigitte, Olivia S. Mitchell, and Beth J. Soldo, eds, Redefining Retirement: How Will Boomers Fare? Oxford, UK: Oxford University Press: 211-233.

Devlin-Foltz, Sebastian, Alice M. Henriques, and John Sabelhaus (2015a). "Is the U.S. Retirement System Contributing to Rising Wealth Inequality?” Unpublished Working Paper. 
Devlin-Foltz, Sebastian, Alice M. Henriques, and John Sabelhaus (2015b). The Evolution of Retirement Wealth. Finance and Economics Discussion Series 2015-9. U.S. Board of Governors of the Federal Reserve System.

Dushi, Irena and Marjorie Honig (2010). "Participation and Contributions in TaxDeferred Retirement Accounts: Evidence from Social Security Records.” Michigan Retirement Research Center WP 2009-219.

Dushi, Irena, Howard M. Iams, and Jules Lichtenstein (2011). “Assessment of Retirement Plan Coverage by Firm Size, Using W-2 Tax Records.” Social Security Bulletin 71(2): 53-65.

Dushi, Irena and Marjorie Honig (2015). "How Much Do Respondents in the Health and Retirement Study Know about Their Contributions to Tax-Deferred Contribution Plans? A Cross-Cohort Comparison.” Journal of Pension Economics and Finance, 14(3): 203-239.

Engen, Eric M., and William G. Gale (1997). "Debt, Taxes, and the Effects of 401(k) Plans on Household Wealth Accumulation.” Mimeo. Brookings.

Fang, Chichun, Charles Brown, and David Weir (2016). "Cohort Changes in Social Security Benefits and Pension Wealth.” Michigan Retirement Research Center WP2016-350.

Fidelity (2018). “How Much Do I Need to Retire?”

https://www.fidelity.com/viewpoints/retirement/how-much-do-i-need-to-retire

Friedberg, Leora and Anthony Webb (2005). "Retirement and the Evolution of Pension Structure.” Journal of Human Resources, 40(2): 281-308.

Ghilarducci, Teresa, Michael Papadopoulos, and Anthony Webb (2017). “Inadequate Retirement Savings for Workers Nearing Retirement.” Schwartz Center for Economic Policy Analysis Policy Note. 
Ghilarducci, Teresa and Hamilton James (2018). "Rescuing Retirement: A Plan to Guarantee Retirement Security for All Americans” Columbia University Press, New York, 2018.

Ghilarducci, Teresa, Michael Papadopoulos, Wei Sun, and Anthony Webb (2018).

"Catch-Up Contributions: An Equitable and Affordable Solution to the Retirement Savings

Crisis.” Public Policy and Aging Report 28(1): S4-S14.

Ghilarducci, Teresa, Michael Papadopoulos, and Anthony Webb (2018). "Forty Percent

of Older Workers and Their Spouses Will Experience Downward Mobility in Retirement.”

Schwartz Center for Economic Policy Analysis and Department of Economics, The New School

for Social Research, Policy Note Series.

Ghilarducci, Teresa, Joelle Saad-Lessler, and Gayle L. Reznik (2018). “Earnings

Volatility and 401(k) Contributions.” Journal of Pension Economics and Finance, 17(4): 554575.

Ghilarducci, Teresa, Siavash Radpour, and Anthony Webb (2019). "Household Economic Shocks Increase Retirement Wealth Inequality.” Schwartz Center for Economic Policy Analysis and Department of Economics, The New School for Social Research, Policy Note Series.

Gustman, Alan L., and Thomas L. Steinmeier (2004). “What people Don’t Know about Their Pension and Social Security: An Analysis Using Linked Data from the Health and Retirement Study," in Gale, William G., John B. Shoven, and Mark J. Warshawsky, eds, Private Pensions and Public Policies. Washington DC: Brookings Institution Press: 57-119.

Gustman, Alan L., Thomas L. Steinmeier, and Nahid Tabatabai (2007). “Imperfect Knowledge of Pension Plan Type.” NBER WP 13379. 
Gustman, Alan L., Thomas L. Steinmeier, and Nahid Tabatabai (2010). Pensions in the Health and Retirement Study. Cambridge, MA: Harvard University Press.

Gustman, Alan L., Thomas L. Steinmeier, and Nahid Tabatabai (2014). "Researcher Contribution: Part III: Pension Wealth Variables 1992-2010.” Health and Retirement Study. Ibbotson Associates (2018). Stocks, Bonds, Bills, and Inflation: 2006 Yearbook. Chicago, IL.

Karamcheva, Nadia S. and Geoffrey T. Sanzenbacher (2010). “Is Pension Inequality Growing?” Issue in Brief 10-1. Chestnut Hill, MA: Center for Retirement Research at Boston College.

Kolodrubetz, Walter W., and Donald M. Landry (1973). “Coverage and Vesting of FullTime Employees Under Private Retirement Plans.” Social Security Bulletin 36(11): 20-36. Laibson, David (1997). “Golden Eggs and Hyperbolic Discounting.” The Quarterly Journal of Economics 112(2): 443-477.

Lusardi, Annamaria, and Olivia S. Mitchell (2013). “The Economic Importance of Financial Literacy: Theory and Evidenc.e” NBER WP 18952.

Lusardi, Annamaria, Pierre-Carl Michaud, and Olivia S. Mitchell (2017). “Optimal Financial Knowledge and Wealth Inequality.” Journal of Political Economy, 125(2): 431-477

Mitchell, Olivia S., and James F. Moore (1997). "Projected Retirement Wealth and Savings Adequacy in the Health and Retirement Study.” NBER WP 6240.

Munnell, Alicia H., Natalia Orlova, and Anthony Webb (2013). “How Important Is Asset Allocation to Financial Security in Retirement?” in Olivia S. Mitchell and Kent Smetters, eds, The Market for Retirement Financial Advice. Oxford, United Kingdom: Oxford University Press: 89-106. 
Munnell, Alicia H., and Dina Bleckman (2014). "Is Pension Coverage a Problem in the Private Sector?” Center for Retirement Research at Boston College Issue Brief 14-7.

Munnell, Alicia H., and Anthony Webb (2015). “The Impact of Leakages from 401(k)s and IRAs.” Center for Retirement Research at Boston College WP 2015-2.

Munnell, Alicia H., Geoffrey T. Sanzenbacher, and Matthew S. Rutledge (2015). "What Causes Workers to Retire Before They Plan?” Center for Retirement Research at Boston College WP 2015-22.

Munnell, Alicia H., Wenliang Hou, Anthony Webb, and Yinji Li (2016). "Pension Participation, Wealth, and Income: 1992-2010.” Center for Retirement Research at Boston College WP 2016-3.

Munnell, Alicia H., Wenliang Hou, and Geoffrey Sanzenbacher (2016). “National Retirement Risk Shows Modest Improvement in 2016” Center for Retirement Research at Boston College Issue Brief 18-1.

Poterba, James, Joshua Rauh, Steven Venti, and David Wise (2006). “Defined Contribution Plans, Defined Benefit Plans, and the Accumulation of Retirement Wealth.” NBER WP 12597.

Poterba, James, Steven Venti, and David A. Wise (2007). “The Rise of 401(k) Plans, Lifetime Earnings, and Wealth at Retirement.” NBER WP 13091.

Rohwedder, Susann (2003). "Measuring Pension Wealth in the HRS: Employer and SelfReports.” Unpublished Manuscript. Santa Monica, CA. RAND Corporation.

Saad-Lessler, Joelle, Teresa Ghilarducci, and Gayle L. Resnik (2018). “Retirement Savings Inequality: Different Effects of Earnings Shocks, Portfolio Selections, and Employer Contributions by Worker Earnings Level.” Social Security Bulletin, 78(3). 
Scholz, John Karl, Ananth Seshadri, and Surachai Khitatrakun (2006). “Are Americans Saving ‘Optimally’ for Retirement?’ Journal of Political Economy, 114(4): 607-643.

Skinner, Jonathan (2007). “Are You Sure You're Saving Enough for Retirement?” Journal of Economic Perspectives, 21(3): 59-80.

Tang, Ning, Olivia S. Mitchell, Gary R. Mottola, and Stephen P. Utkus (2010). “The Efficiency of Sponsor and Participant Portfolio Choices in 401(k) Plans.” Journal of Public Economics, 94(11-12): 1073-1085.

United States Government Accountability Office (GAO, 2012). “401(k) Plans: Increased Educational Outreach Broader Oversight May Reduce Plan Fees.” GAO-12-325. Washington, DC: GPO.

United States Government Accountability Office (GAO, 2014). “Individual Retirement Accounts: IRS Could Bolster Enforcement of Multimillion Dollar Accounts, but More Direction from Congress is Needed.” GAO-15-16. Washington, DC: GPO.

United States Government Accountability Office. (GAO, 2016). “401(k) Plans: Effects of Eligibility and Vesting Policies on Workers' Retirement Savings.” GAO-17-69. Washington, DC: GPO.

VanDerhei, Jack, Sarah Holden, Craig Copeland and Luis Alonso (2012). “401(k) Plan Asset Allocation, Account Balances, and Loan Activity in 2011.” EBRI Issue Brief 380. Washington, DC: Employee Benefit Research Institute.

VanDerhei, Jack, Sarah Holden, Luis Alonso, and Steven Bass (2018). “401(k) Plan Asset Allocation, Account Balances, and Loan Activity in 2016.” EBRI Issue Brief 458. Washington, DC: Employee Benefit Research Institute. 
Vanguard (2014). “How America Saves 2014: A Report on Vanguard 2013 Defined Contribution Plan Data.” Valley Forge, PA.

Venti, Steven F., and David A. Wise (1998). "The Cause of Wealth Dispersion at Retirement: Choice or Chance?” The American Economic Review, 88(2): 185-191.

Venti, Steven F (2011). “Economic Measurement in the Health and Retirement Study.” Forum for Health Economics \& Policy, 14 (3): 1-20.

Wolff, Edward (2015). “U.S. Pensions in the 2000s: the Lost Decade?” Review of Income and Wealth, 61(4): 599-629.

Wu, April and Matthew S. Rutledge (2014). "Lower Income Individuals Without Pensions: Who Misses Out and Why?” Center for Retirement Research WP 2014-2. 
Table 1: Sample attrition. Source: Author's calculations.

\begin{tabular}{|c|c|c|c|c|}
\hline & Survey & ear & & \\
\hline & 1992 & 1998 & 2004 & 2010 \\
\hline New respondents in the wave & 12,652 & 4,956 & 3,446 & 6,414 \\
\hline Ages 51 to 56 & 5,568 & 1,847 & 2,531 & 3,952 \\
\hline Employees & 3,326 & 1,200 & 1,613 & 2,278 \\
\hline $\begin{array}{l}\text { Started Job at least a year before beginning of the } \\
\text { survey }\end{array}$ & 2,884 & 987 & 1,362 & 1,892 \\
\hline Have W-2 Records in the Master Earnings Records & 2,413 & 762 & 942 & 750 \\
\hline No Errors in W-2s: Final Sample & 2,035 & 592 & 859 & 669 \\
\hline
\end{tabular}

Table 2: SPD type by self-reported plan type and wave. Source: Author's calculations.

\begin{tabular}{|c|c|c|c|c|c|}
\hline \multirow[b]{2}{*}{ Wave } & \multirow{2}{*}{$\begin{array}{l}\text { Self-reported Plan } \\
\text { Type }\end{array}$} & \multicolumn{4}{|c|}{ SPD Type } \\
\hline & & No SPD & $\begin{array}{l}\text { Only DB } \\
\text { SPD }\end{array}$ & $\begin{array}{l}\text { Only DC } \\
\text { SPD }\end{array}$ & $\begin{array}{l}\text { Both DB and DC } \\
\text { SPDs }\end{array}$ \\
\hline \multirow{4}{*}{1992} & DB only & $29.0 \%$ & $41.9 \%$ & $8.0 \%$ & $21.1 \%$ \\
\hline & DC only & $49.2 \%$ & $15.9 \%$ & $23.5 \%$ & $11.4 \%$ \\
\hline & Both DB and DC & $27.4 \%$ & $35.3 \%$ & $9.5 \%$ & $27.8 \%$ \\
\hline & Any Plan & $34.8 \%$ & $32.1 \%$ & $13.3 \%$ & $19.8 \%$ \\
\hline \multirow{4}{*}{1998} & DB only & $44.8 \%$ & $13.0 \%$ & $5.5 \%$ & $36.7 \%$ \\
\hline & DC only & $60.5 \%$ & $3.5 \%$ & $23.9 \%$ & $12.1 \%$ \\
\hline & Both DB and DC & $46.4 \%$ & $13.5 \%$ & $9.7 \%$ & $30.4 \%$ \\
\hline & Any Plan & $51.4 \%$ & $9.5 \%$ & $13.9 \%$ & $25.2 \%$ \\
\hline \multirow{4}{*}{2004} & DB only & $42.7 \%$ & $19.3 \%$ & $5.4 \%$ & $32.6 \%$ \\
\hline & DC only & $72.3 \%$ & $6.2 \%$ & $13.5 \%$ & $8.0 \%$ \\
\hline & Both DB and DC & $47.9 \%$ & $14.9 \%$ & $9.9 \%$ & $27.3 \%$ \\
\hline & Any Plan & $58.9 \%$ & $11.6 \%$ & $10.6 \%$ & $18.9 \%$ \\
\hline \multirow{4}{*}{2010} & DB only & $49.8 \%$ & $50.2 \%$ & $0.0 \%$ & $0.0 \%$ \\
\hline & DC only & $83.3 \%$ & $16.7 \%$ & $0.0 \%$ & $0.0 \%$ \\
\hline & Both DB and DC & $60.4 \%$ & $39.6 \%$ & $0.0 \%$ & $0.0 \%$ \\
\hline & Any Plan & $69.5 \%$ & $30.5 \%$ & $0.0 \%$ & $0.0 \%$ \\
\hline
\end{tabular}

Note: Self-reported plan types are extracted from RAND HRS. No sample weights, to provide comparability with Gustman, Steinmeier, and Tabatabai (2010). Sample includes all workers who joined in the relevant wave and self-report having a retirement plan in their current job. 
Table 3: Percentage with non-zero W-2 elective deferrals in 1991 by self-reported plan type and SPD type in 1992 wave. Source: Author's calculations.

\begin{tabular}{lllllll}
\multicolumn{7}{c}{ SPD Type } \\
\cline { 3 - 7 } & & No SPD & Only DB & Only DC & $\begin{array}{l}\text { Both DB } \\
\text { and DC }\end{array}$ & All \\
\cline { 3 - 7 } & Only DB & $18.3 \%$ & $21.8 \%$ & $22.7 \%$ & $26.1 \%$ & $21.8 \%$ \\
Self - & Only DC & $40.9 \%$ & $39.6 \%$ & $51.3 \%$ & $52.0 \%$ & $44.5 \%$ \\
Reported & Both DB & & & & & \\
Plan Type & and DC & $62.9 \%$ & $79.0 \%$ & $66.0 \%$ & $74.2 \%$ & $72.2 \%$ \\
\cline { 2 - 7 } & All & $37.6 \%$ & $40.7 \%$ & $46.5 \%$ & $49.6 \%$ & $42.2 \%$ \\
\hline Note: Sample includes all respondents with available W-2 information in 1991 who have non- \\
missing values for elective deferrals (Box 12).
\end{tabular}

Table 4: Share of total retirement wealth by earnings quintile and top 10\% of earners 19922010. Source: Author's calculations

\begin{tabular}{lllll}
\hline Earnings Quintile & $\mathbf{1 9 9 2}$ & $\mathbf{1 9 9 8}$ & $\mathbf{2 0 0 4}$ & $\mathbf{2 0 1 0}$ \\
Q1 & 0.03 & 0.02 & 0.01 & 0.01 \\
Q2 & 0.06 & 0.09 & 0.07 & 0.06 \\
Q3 & 0.15 & 0.16 & 0.17 & 0.14 \\
Q4 & 0.27 & 0.26 & 0.27 & 0.29 \\
Q5 & 0.49 & 0.48 & 0.48 & 0.50 \\
Top 10\% of earners & 0.31 & 0.30 & 0.30 & 0.29
\end{tabular}

Note: Cross-Wave Social Security sample Weights. 


\begin{tabular}{|c|c|c|c|c|c|c|c|}
\hline Year & $\begin{array}{l}\text { Earnings } \\
\text { Quintile }\end{array}$ & P10 & P25 & P50 & P75 & P90 & $\begin{array}{l}\text { Share } \\
\text { with no } \\
\text { wealth }\end{array}$ \\
\hline \multirow{6}{*}{1992} & Q1 & $\$ 0$ & $\$ 0$ & $\$ 1,900$ & $\$ 18,700$ & $\$ 37,600$ & $45.4 \%$ \\
\hline & Q2 & $\$ 0$ & $\$ 0$ & $\$ 18,000$ & $\$ 43,800$ & $\$ 77,700$ & $26.0 \%$ \\
\hline & Q3 & $\$ 500$ & $\$ 17,800$ & $\$ 45,900$ & $\$ 99,800$ & $\$ 176,600$ & $9.5 \%$ \\
\hline & Q4 & $\$ 11,800$ & $\$ 39,800$ & $\$ 93,100$ & $\$ 162,500$ & $\$ 263,800$ & $5.4 \%$ \\
\hline & Q5 & $\$ 34,200$ & $\$ 79,500$ & $\$ 175,500$ & $\$ 315,100$ & $\$ 492,900$ & $1.2 \%$ \\
\hline & All & $\$ 0$ & $\$ 8,000$ & $\$ 40,900$ & $\$ 122,200$ & $\$ 257,000$ & $17.5 \%$ \\
\hline \multirow{6}{*}{1998} & Q1 & $\$ 0$ & $\$ 0$ & $\$ 1,800$ & $\$ 13,500$ & $\$ 42,300$ & $47.8 \%$ \\
\hline & Q2 & $\$ 0$ & $\$ 13,700$ & $\$ 35,200$ & $\$ 75,500$ & $\$ 184,500$ & $10.8 \%$ \\
\hline & Q3 & $\$ 3,500$ & $\$ 33,000$ & $\$ 81,400$ & $\$ 179,100$ & $\$ 247,200$ & $7.0 \%$ \\
\hline & Q4 & $\$ 29,400$ & $\$ 85,600$ & $\$ 145,600$ & $\$ 270,800$ & $\$ 391,000$ & $5.4 \%$ \\
\hline & Q5 & $\$ 67,600$ & $\$ 150,300$ & $\$ 279,600$ & $\$ 441,900$ & $\$ 828,100$ & $1.2 \%$ \\
\hline & All & $\$ 0$ & $\$ 13,700$ & $\$ 76,700$ & $\$ 214,600$ & $\$ 385,300$ & $14.2 \%$ \\
\hline \multirow{6}{*}{2004} & Q1 & $\$ 0$ & $\$ 0$ & $\$ 100$ & $\$ 18,700$ & $\$ 37,600$ & $49.9 \%$ \\
\hline & Q2 & $\$ 0$ & $\$ 3,500$ & $\$ 24,700$ & $\$ 80,800$ & $\$ 179,800$ & $21.4 \%$ \\
\hline & Q3 & $\$ 5,600$ & $\$ 39,200$ & $\$ 96,100$ & $\$ 238,700$ & $\$ 429,200$ & $7.4 \%$ \\
\hline & Q4 & $\$ 15,200$ & $\$ 53,200$ & $\$ 198,200$ & $\$ 374,300$ & $\$ 585,000$ & $7.0 \%$ \\
\hline & Q5 & $\$ 55,500$ & $\$ 162,900$ & $\$ 336,300$ & $\$ 609,100$ & $\$ 915,000$ & $2.0 \%$ \\
\hline & All & $\$ 0$ & $\$ 10,900$ & $\$ 68,300$ & $\$ 258,400$ & $\$ 522,000$ & $17.3 \%$ \\
\hline \multirow{6}{*}{2010} & Q1 & $\$ 0$ & $\$ 0$ & $\$ 0$ & $\$ 7,800$ & $\$ 40,500$ & $51.2 \%$ \\
\hline & Q2 & $\$ 0$ & $\$ 100$ & $\$ 20,000$ & $\$ 69,300$ & $\$ 110,600$ & $24.1 \%$ \\
\hline & Q3 & $\$ 300$ & $\$ 19,000$ & $\$ 75,700$ & $\$ 137,900$ & $\$ 273,300$ & $9.4 \%$ \\
\hline & Q4 & $\$ 4,100$ & $\$ 50,000$ & $\$ 170,100$ & $\$ 355,800$ & $\$ 488,900$ & $6.9 \%$ \\
\hline & Q5 & $\$ 97,000$ & $\$ 144,200$ & $\$ 294,700$ & $\$ 505,400$ & $\$ 837,800$ & $2.2 \%$ \\
\hline & All & $\$ 0$ & $\$ 4,300$ & $\$ 67,000$ & $\$ 191,800$ & $\$ 426,700$ & $18.6 \%$ \\
\hline
\end{tabular}

Note: All amounts are in $\$ 2010$. HRS sample weights. 


\begin{tabular}{|c|c|c|c|c|c|c|}
\hline Year & $\begin{array}{l}\text { Earnings } \\
\text { Quintile }\end{array}$ & P10 & P25 & P50 & P75 & P90 \\
\hline \multirow{5}{*}{1992} & Q1 & 0.00 & 0.00 & 0.25 & 1.56 & 3.79 \\
\hline & Q2 & 0.00 & 0.00 & 0.71 & 1.66 & 2.96 \\
\hline & Q3 & 0.01 & 0.46 & 1.18 & 2.50 & 4.16 \\
\hline & Q4 & 0.23 & 0.78 & 1.64 & 2.87 & 4.94 \\
\hline & Q5 & 0.38 & 0.97 & 1.97 & 3.42 & 5.09 \\
\hline \multirow{5}{*}{1998} & Q1 & 0.00 & 0.00 & 0.10 & 0.94 & 2.69 \\
\hline & Q2 & 0.00 & 0.44 & 1.05 & 2.14 & 5.09 \\
\hline & Q3 & 0.06 & 0.59 & 1.73 & 3.47 & 5.00 \\
\hline & Q4 & 0.49 & 1.20 & 2.17 & 3.52 & 5.17 \\
\hline & Q5 & 0.53 & 1.33 & 2.57 & 3.65 & 5.32 \\
\hline \multirow{5}{*}{2004} & Q1 & 0.00 & 0.00 & 0.01 & 1.44 & 3.16 \\
\hline & Q2 & 0.00 & 0.15 & 0.80 & 2.77 & 6.50 \\
\hline & Q3 & 0.17 & 0.85 & 2.32 & 6.12 & 10.10 \\
\hline & Q4 & 0.28 & 0.88 & 3.16 & 5.96 & 10.16 \\
\hline & Q5 & 0.62 & 1.63 & 3.37 & 5.35 & 9.02 \\
\hline \multirow{5}{*}{2010} & Q1 & 0.00 & 0.00 & 0.00 & 0.44 & 1.80 \\
\hline & Q2 & 0.00 & 0.00 & 0.73 & 2.15 & 3.82 \\
\hline & Q3 & 0.01 & 0.39 & 1.51 & 2.64 & 5.14 \\
\hline & Q4 & 0.07 & 0.79 & 2.37 & 4.97 & 6.78 \\
\hline & Q5 & 0.75 & 1.21 & 2.43 & 4.72 & 8.24 \\
\hline
\end{tabular}


Table 7: Theil Index of Retirement Wealth Inequality by Year and Plan. Source: Author's calculations.

\begin{tabular}{llllll}
\hline Year & $\begin{array}{l}\text { DC } \\
\text { only }\end{array}$ & DB only & DB \& DC Any & $\begin{array}{l}\text { All } \\
\text { workers }\end{array}$ & $\begin{array}{l}\text { Any } \\
\text { retirement } \\
\text { Plan }\end{array}$ \\
\hline $\mathbf{1 9 9 2}$ & 0.703 & 0.623 & 0.438 & 0.794 & 0.602 \\
$\mathbf{2 0 1 0}$ & 0.724 & 0.583 & 0.381 & 0.819 & 0.613 \\
\hline
\end{tabular}

Table 8: Percentage with retirement wealth from current and previous jobs. Source: Author's calculations.

\begin{tabular}{llllll}
\hline & Year & DB & DC & Both & Any plans \\
\cline { 2 - 6 } Only Current Job & $\mathbf{1 9 9 2}$ & $53.6 \%$ & $45.1 \%$ & $27.4 \%$ & $71.2 \%$ \\
& $\mathbf{2 0 1 0}$ & $45.6 \%$ & $61.5 \%$ & $30.9 \%$ & $76.2 \%$ \\
\hline \multirow{2}{*}{ Current and Previous Job } & $\mathbf{1 9 9 2}$ & $57.1 \%$ & $66.5 \%$ & $40.9 \%$ & $82.7 \%$ \\
& $\mathbf{2 0 1 0}$ & $46.4 \%$ & $71.0 \%$ & $36.0 \%$ & $81.4 \%$ \\
\hline
\end{tabular}

Note: Cross-Wave Social Security Weights.

Table 9: Wealth to Earnings Ratio at its 10th, 25th, 50th, 75th and 90th Percentiles of those with non-zero retirement wealth for each Earnings Quintile in 1992, 1998, 2004, and 2010. Source: Author's calculations

\begin{tabular}{|c|c|c|c|c|c|c|}
\hline Year & $\begin{array}{c}\text { Earnings } \\
\text { Quintile }\end{array}$ & P10 & P25 & P50 & P75 & P90 \\
\hline \multirow{5}{*}{1992} & Q1 & 0.26 & 0.65 & 1.42 & 3.25 & 5.86 \\
\hline & Q2 & 0.26 & 0.58 & 1.11 & 2.30 & 3.50 \\
\hline & Q3 & 0.26 & 0.67 & 1.33 & 2.69 & 4.88 \\
\hline & Q4 & 0.41 & 0.90 & 1.81 & 3.07 & 5.18 \\
\hline & Q5 & 0.48 & 0.99 & 2.01 & 3.42 & 5.09 \\
\hline \multirow{5}{*}{1998} & Q1 & 0.14 & 0.39 & 0.94 & 2.39 & 4.23 \\
\hline & Q2 & 0.29 & 0.62 & 1.26 & 2.22 & 5.33 \\
\hline & Q3 & 0.29 & 0.80 & 1.79 & 3.61 & 5.07 \\
\hline & Q4 & 0.76 & 1.28 & 2.38 & 3.58 & 5.37 \\
\hline & Q5 & 0.63 & 1.38 & 2.57 & 3.65 & 5.32 \\
\hline \multirow{5}{*}{2004} & Q1 & 0.18 & 0.55 & 1.44 & 2.73 & 3.89 \\
\hline & Q2 & 0.27 & 0.49 & 1.52 & 3.62 & 8.84 \\
\hline & Q3 & 0.46 & 1.23 & 2.96 & 6.17 & 10.44 \\
\hline & Q4 & 0.50 & 1.28 & 3.54 & 6.09 & 10.16 \\
\hline & Q5 & 0.73 & 1.78 & 3.37 & 5.93 & 9.10 \\
\hline \multirow{5}{*}{2010} & Q1 & 0.04 & 0.18 & 0.46 & 1.70 & 3.80 \\
\hline & Q2 & 0.11 & 0.43 & 1.56 & 2.43 & 4.15 \\
\hline & Q3 & 0.20 & 0.60 & 1.84 & 2.70 & 5.49 \\
\hline & Q4 & 0.38 & 0.93 & 2.50 & 5.00 & 7.36 \\
\hline & Q5 & 0.83 & 1.24 & 2.54 & 4.72 & 8.24 \\
\hline
\end{tabular}


Table 10: Retirement wealth inequality by earnings quintile. Source: Author's calculations.

\begin{tabular}{|c|c|c|c|c|c|c|}
\hline \multirow[b]{2}{*}{ Year } & \multirow[b]{2}{*}{ Measure } & \multicolumn{5}{|c|}{ Earnings quintile } \\
\hline & & Q1 & Q2 & Q3 & Q4 & Q5 \\
\hline 1992 & Theil & 1.203 & 0.776 & 0.647 & 0.512 & 0.423 \\
\hline 1998 & Theil & 1.220 & 0.667 & 0.432 & 0.290 & 0.305 \\
\hline 2004 & Theil & 1.118 & 0.782 & 0.465 & 0.430 & 0.344 \\
\hline 2010 & Theil & 1.410 & 0.699 & 0.504 & 0.446 & 0.315 \\
\hline
\end{tabular}

Note: Cross-Wave Social Security Weights. 